\title{
Exchanges with the Dead
}

\section{Exhuming Human Remains among the Ibaloy of Upper Loacan (Philippines)}

\author{
Frédéric Laugrand \\ Université catholique de Louvain, Louvain-la-Neuve, Belgium \\ frederic.laugrand@uclouvain.be
}

\author{
Antoine Laugrand \\ Université catholique de Louvain, Louvain-la-Neuve, Belgium \\ antoinelaugrand@gmail.com
}

\author{
Jazil Tamang \\ Barangay of Loacan, Itogon, Benguet, Philippines \\ ziel_52945@yahoo.com
}

\author{
Gliseria Magapin \\ Barangay of Loacan, Itogon, Benguet, Philippines \\ glizzymilton@gmail.com
}

\begin{abstract}
The Ibaloy, an indigenous group of the Cordillera Central in the Philippines, perform complex burial rites. Often when someone falls ill, they also exhume human remains, a practice that has not received the attention it deserves in a cosmology where animism and analogism are intertwined. Here, we describe a variant of the késheng ja waray batbat ritual observed in 2017, the timeline of its sequences, and the many objects and acts it involves. This ritual is key to the exchanges that the living make with the dead. In it, pigs act more as 'connectors' than as sacrificial offerings, and their flesh, blood, and karashowa (soul) are used and shared. This three-day ritual questions death as the end of life, and sheds light on the extent to which Hertz's 'second funeral' concept is useful in understanding the relationships between the living and the dead. It also illuminates how the dead need continuous help from the living and vice versa. Both groups strive to reach a state of diteng (well-being, healthiness) which can be reached only after the dead themselves experience it, thanks to the efforts of the living who take care of their remains and make offerings to them. Then, luck and prosperity can be expected from


the dead. These exchanges appear to be necessary to live a good life, and they must be repeated and maintained at all cost.

\section{Keywords}

death - funerary rites - exhumation - exchanges - pigs - Ibaloy - Philippines

\section{Introduction}

Exhuming the remains of those who died by violence is well known in countries where conflicts or civil wars occurred. Exhumations also happen in societies where the practice is part of the living's duty to take care of their deceased. Exhumation of human remains is practised in several regions of Mexico and Columbia, notably by the Wayùu (Simon 2019), in Madagascar (Bloch 1971; Fournel 1962), and in Indonesia. ${ }^{1}$ In the Philippines, exhumation is especially persistent in the Cordillera Central of Luzon. Jon Remme (2014:113-26) described it among the neighbouring Ifugao, saying it may take place several times if need be and never only once - a description that also applies to the Ibaloy. Exhumation among the Ibaloy, however, is not a 'second funeral', a longused term that Robert Hertz (1928) coined for a ceremony meant to normalize relations between the living and their dead. Among the Ibaloy of Loacan Barangay (the smallest administrative unit) in the municipality of Itogon in Benguet Province, who are the focus of this article, the spirits of the dead, the kedaring, are summoned in daily life and in many rituals not so much to honour them as to seek their help in providing happiness and prosperity to the living. The most important thing is to experience diteng (well-being, healthiness) which can be reached only after the dead themselves experience it, thanks to the efforts of the living who take care of their remains and make offerings to them. Then, luck and prosperity can be expected from the dead. No one should give and explicitly expect something back, however, as this attitude would lead to bad luck and poverty.

1 We express our gratitude to Maurice Bloch, Robert Crépeau, Jean-Guy Goulet, André Iteanu, Marie Mauzé, and Lionel Simon for their generous comments on a former version of this article, as well as the two anonymous reviewers. However, the ideas that are developed here are purely those of the authors. Thank you also to Peter Frost and Joanne Muzak for revising our English. 
Exhumation is largely ignored in the ethnographic literature on this Cordilleran region, although much has been written on funerary rites. ${ }^{2}$ Among some Ibaloy of the province of Benguet, exhumation rituals are still performed, which confirms the vitality of Igorot traditions (Russell 1989) and the importance of religion (Lewis 1992), but no anthropologist has ever studied them. Patricia Okubo Afable (1975) vividly described the aremag, the first funeral of the Ibaloy, but not their second funeral. She writes:

Unlike other societies described in the literature, the Ibaloy do not live in continual fear and anxiety about the spirits around them. Obligations to supernaturals are fulfilled in the performance of offerings or in the perfunctory gestures (linguistic or otherwise) which an individual executes as expressions of his awareness of the need to honor the dead or to be respectful towards forest or water spirits. Once these needs have been attended to, the spirits are forgotten for a while, until some new crisis makes it necessary to call upon one of their kind again.

AFABLE 1975:107

Afable refers to incidental crises. The exhumation rites are precise, excellent examples of responses to a crisis, as they are performed after 'a problem' has been identified by a mambonong, a ritual officiant or a kind of shaman. Their absence in the literature remains to be explained, since the Ibaloy have been extensively written about. ${ }^{3}$

In the course of several projects to help pass on traditional knowledge from elders to youths, we have had the opportunity to work with the Loacan community. We have been conducting fieldwork there each year since 2012 and have organized several workshops attended by more than twenty elders and around ten young people. Additional fieldwork was conducted by Antoine Laugrand from February to July 2020. Jazil Tamang and Gliseria Magapin are Ibaloy themselves and helped a great deal with the research, especially by sharing their experiences and understandings of exhumation and funerary rites. Films have been recorded and edited with their cooperation, including one on the

2 Afable 1975; Canol 1981; Celino 199o; Laban 1995; Piluden-Omengan 2004. In the literature, the $k a-i l$ is only referred to as a second burial (see Chimcas et al. 2011:219).

3 The very first ethnographers, such as Moss $(1920)$ and Scott $(1958,1994)$ provided a wealth of information about Ibaloy traditions, but they do not refer to these practices either. See also Moss and Kroeber 1919; Ballard 1978, and Russell 1989. Pungayan (1980) described their kinship system, their history, and their language (see also Pungayan and Picpican 1978); Bagamaspad and Hamada-Pawid (1985) compiled some of their oral stories; and Prill-Brett (1992) studied their customary law and their use of land resources. 
exhumation of human remains, and a second one on aremag (funerals). These films, along with various other audiovisual recordings and texts, have been published elsewhere. ${ }^{4}$ In this article, we focus on one three-day exhumation ritual recorded in 2017, which included the family of the deceased individuals, nearly 100 participants, and 11 pigs. ${ }^{5}$ We broaden our discussion of the filmed ritual by drawing on additional information collected over the years.

In the Cordillera of Luzon, the dead are seen as still partly alive. They no longer reproduce sexually, but their numbers increase. Above all, they act and react in response to the practices of the living. If they are well treated, they feel well and do not interfere with the living. However, they can also punish living people who do not respect them by making them sick. They might take possession of a person's body to express themselves, as can be seen in the shepo (possession) recorded in the film. They feed on pigs and need a multitude of things to get by in their lives after death.

While the first funeral cycle (aremag) is to be understood as a rite of passage and a crossing of a threshold, this is no longer the case when the remains are exhumed. Instead, the second funeral appears as a key moment for dining together, a ceremony of commensality during which the living eat with their dead, hoping to mingle with and then separate from them. Maurice Bloch stressed the importance of eating in funerary rites: 'Commensality evokes a dialectical process of temporal unification and diversification. Eating the same food will unite bodies that eat together, and eating different foods will distance them from each other' (Bloch 2010:85). This description applies aptly to the Ibaloy. At the time of exhumation, they eat rice and pork with their dead, who eat the dowag, the steam rising from the cooking pots.

When dealing with the subject of death, anthropologists have often sought to understand how the living transform the corpses of their dead into ancestors. A key stage is the second funeral, when human remains are transferred to another burial place. ${ }^{6}$ According to Hertz and his followers, this marks the

4 Laugrand, Laugrand, Tamang and Milton 2019a, 2019b, and 2019c.

5 The film of the three-day exhumation ritual can be watched here: https://www.youtube.com/ watch?v=NFUSgaSpgjw. We wish to thank the Teres family, who permitted us to film the ritual and take photos. We would also like to thank the elders of Loacan for their assistance, especially Lolo Melanio. Our gratitude also goes to the Fonds National de la Recherche Scientifique (FNRS) for awarding Frédéric Laugrand a Mandat Ulysse (grant no F. 6oo2.17), and Antoine Laugrand a FRESH doctoral scholarship, which paid for part of this fieldwork.

6 See, for example, the chapters on Borneo in the collective work edited by Couderc and Sillander (2012), which show the diverse ways in which the dead are transformed into ancestors, even including 'rebirth' (Couderc 2007). On death in Southeast Asia, see also Metcalf 1982 and Wilder 2003. 
end of the bereaved's ritual obligations, with the deceased's soul now moving on to post-mortem places. The living are healed, and their society is renewed. Huntington and Metcalf (1979) followed Hertz's intuitions and stressed the celebration of life that flows from this feast of the dead. Bloch and Parry (1982) highlighted the role of fertility, sexuality, and, more broadly, vitality in burial practices. ${ }^{7}$ These perspectives are fruitful for understanding the Ibaloy practices.

But these observations apply to the Ibaloy only in part. The aremag, the first funeral, does indeed serve to manage a living person's departure for the next world. Funerals last between four and nine days and involve various rituals, and the dead is provided with a 'lunch box' (balon) containing two eggs, rice, and chicken meat. The burial has to take place when the moon is present, and the dead body has to point towards the east. Death immediately activates a series of prohibitions or taboos that the Ibaloy call ngilin, which forbid work and sexual relations. Without these prohibitions, rituals are useless and powerless. Meanwhile, the deceased loses his/her karashowa (soul) and becomes one of the kedaring (a deceased spirit). ${ }^{8}$ Yet death does not exclude an Ibaloy from social life. The dead and the living continue to deal with each other; the living provide the dead with pigs and objects while caring for their remains, keeping them dry, and protecting them from termites and other impurities. In these dealings, the living have two main motives. First, they wish to keep the dead, at all costs, from bothering them with requests or inflicting illnesses on them (which might happen if some rituals are carried out improperly). In this sense, Bloch is right: the living perform the rituals to rid themselves of the dead. But they also want more. They expect that by performing the rituals properly, they might reach a state of diteng, 'feeling well'. And second, they hope for blessings, prosperity, health, luck, and fortune. Separated from their dead by geographic distance and because their needs are no longer quite the same, the living still

7 Cederroth, Corlin and Lindström (1988), Bloch (1993), and Godelier (2014) have also written on death and post-mortem places. Their articles centre on the concept of person, the meaning of death, and conceptions of the afterlife. For a different perspective, see Delaplace (2009).

8 We use the notions of 'soul' and 'spirit' as used by the Ibaloy. They distinguish the karashowa (the soul) or kadkadwa (literally 'second', pair, double) from the kedaring (the deceased spirit). The living ones, the animals as well as the objects (such as sheets and blankets, clothes, money, and food), are all said to possess a karashowa that can be given to the deceased through the offerings made for them. Moss (1920:273) already noticed this: 'Blankets, cloth, money, and food have souls, which are taken by the spirits of the dead when there are ceremonies.' Both karashowa and kedaring can be seen by certain people, such as the mambonong, who have been given the ability to see them; they are both similar to the form of the living person's body. 
invite them to eat together, even if the dead are invisible. The Ibaloy explain that before each meal one must loudly say Kalejo mengan (literally: 'Let's eat'), to inform the dead and invite them to the table. As in many societies, it is often through dreams that one communicates with the dead. The dead may also warn the living about prospective dangers by sending signs in the form of animals, such as snakes that appear surreptitiously on roads or in homes.

What motivates the dead in these exchanges? How do they need the living? Could it be that the dead remember their descendants and expect support from them with each death, as the living are able to provide them with money and pigs, and thus help them to live better in the hereafter? At a funeral, we know that the living always give money to the deceased person for distribution to other dead people when he/she goes to the post-mortem place-a tradition known as opo. In the exhumation rituals, the Ibaloy emphasize that the dead always need pigs, so they offer them the karashowa of a pig for them to raise it. To borrow Remme's expression used regarding the Ifugao, 'pigs make kin' (Remme 2014:27) — but not just for the living, we should add.

This exchange between the living and the dead is crucial in the késheng ja waray batbat ritual - the subject of this article. It raises the question of the dead having many modes of existence, an idea put forward by Berthod (2005:534). They exist in different ways. They may be scattered in daily life, or they may come together for rituals where they act and eat like any living person. They are dead, but their appearance is similar to when they were living. Far from marking the end of life, death is seen as a parallel way of living. New opportunities as well as duties emerge on both sides.

Here, we examine the pig's role, how it is butchered, and what divinatory role it plays. By reading its liver, the living can tell how satisfied the dead are and measure the luck they are given. The pig's flesh, blood, and karashowa have equally specific destinies. We argue that the pig looks more like a 'connector' than a sacrificial victim. Offerings to the dead are a necessary counterpart for the living to obtain luck, protection, and benediction. We will see that this ritual enables the living to exchange with their dead and reach diteng. As Hertz and Bloch clearly understood, the 'dead' of the ritual are no longer alive-but they are not totally dead either. The two groups evolve in different worlds, but they remain interconnected through exchanges.

The first part of this article provides some contextual information. We then describe the exhumation ritual in detail and move to a discussion. 

Loacan

The Ibaloy of Upper Loacan inhabit a barangay of Itogon in the southern portion of the province of Benguet, which is next to Baguio City, the capital of the Cordillera. Although they practise terrace farming, as do all other Igorot groups (see Conklin, Lupaih and Pinther 1980; Scott 1958), they also mine gold on a small scale, having traded in this metal for centuries with the Chinese, Spanish, and Americans (Cabellero 1996; Canilao 2011). The community of Loacan is mostly Catholic, but other denominations, such as evangelical churches, are present. The group we stayed with had long ago been evangelized by the Missionary Sisters of the Immaculate Conception and by priests from several religious orders, notably American Jesuits. Christian identity is important to the Ibaloy, and we took part in several Christian ceremonies with them, including Palm Sunday, but it has not erased the traditions the elders wish to preserve, as Christian celebrations are separated from Ibaloy rituals.

With the help of the elders, we identified over 40 rituals. Each ritual has several sequences that are coherent units in their own right, or bricks, to use André Iteanu's (2019) term when discussing the Orokaiva of New Guinea in his film Les Possédés et leurs mondes. These sequences are ordered differently depending on the ritual. They can be combined in various ways. Some sequences can be added and that makes a new ritual. Moreover, there is a wide variety of practices, with each village having its own variants. Most of the rituals require pigs, which in the past were wild but today are domestic. Sometimes, chickens, ducks, water buffalo (carabao), cows, and dogs are also used.

The different sequences of the késheng ja waray batbat are presented following their chronological order. The poni sequence begins the ritual with a divination on the first day. It consists in calling the kedaring to join the ritual. Next comes the ka-il sequence: exhuming the dead, cleaning their bones, and tidying up the burial place. The inkaringan sequence is the time for honouring the requests of the dead, making offerings, and dancing the tayaw with them. These performances close the evening of the first day. On the second day, the batbat sequence includes the main feast and many ritual formulas addressed to the kabunian, the Ibaloy divinities. The sinekgowit sequence involves appealing again to the Ibaloy divinities for their protection. The third day brings the kape sequence: the acceptance of the gifts. It ends the ritual.

The késheng ja waray batbat may be performed many times in a lifetime but only after a year has passed after the aremag, the first funeral, and when 
a kedaring has asked the living for this ritual. Often such requests are made through a recurring dream or an illness, and after consulting an elder or a mambonong, who will advise on the type of ritual to be performed, the requests are fulfilled.

In the following case, the father has suffered from a migraine and a cold for several days and has dreamed about his own father, now dead, playing the gong. He consults a mambonong, who tells him that his dead son is causing the illness. He advises him to perform the késheng ja waray batbat ritual and to exhume the bodies of both his son and his father (the family's grandfather). As such, the ritual clearly results from an incidental crisis.

\subsection{The Poni Sequence}

On the first day, the father and his family perform the poni to inform the kedaring (deceased family members) that the ritual will be conducted for them. A relative slits the throat of a rooster and a hen, and their blood is gathered in two separate dishes and examined by the mambonong and the family, who try to see a good omen in the blood. The food and the rice wine are consumed not only by the family and the guests but also by the deceased they have invited. The latter feed on the dowag, the steam rising from the rice and meat being cooked, whereas the living eat the apag, the meat. The deceased are offered 16 plates of meat. Separate plates are prepared for those who died from an accident or suicide, because they are not to mix with those who died of other causes. Holding the chicken and saying his madmad (a ritual formula), the mambonong utters the names of all the kabunian, the gods of the Ibaloy, and gets their attention for the coming ritual. A similar operation happens just before eating the meal, when the mambonong utters in his bonong (a ritual prayer) the names of the deceased mambonong who were given power by the kabunian. Thus, the poni opens the ritual, and the elders and the mambonong make their predictions ( padto), depending on whether they have seen a good omen or a bad one.

\subsection{The Ka-il Sequence}

The next day, the father and his family first exhume the grandfather from his cement tomb. Because the father dreamed about him, the group assumes that the grandfather's kedaring was warning his son about the existence of a problem with the dead grandson. The father has therefore asked that the ritual be performed. The grandfather's corpse is placed on a kolebaw sheet. The closest family members clean his bones and delicately put them back in order on a shindi sheet (see Figure 1). The widow and the parents are not allowed to do this, and a mambonong often takes care of this operation. Dirt and impurities 


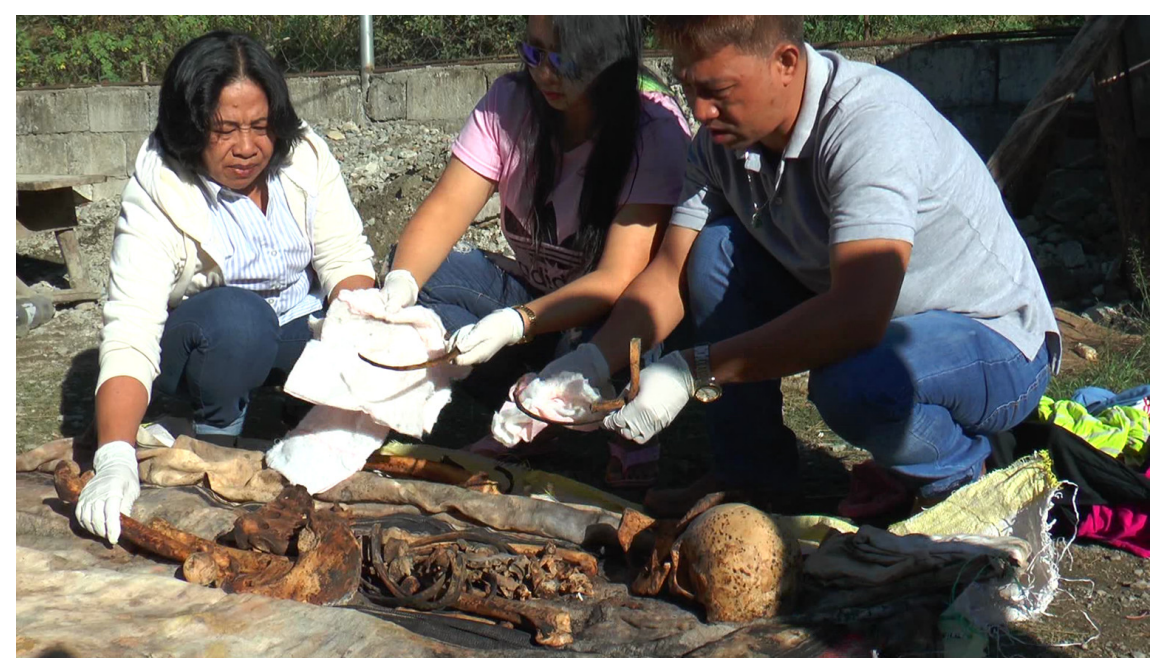

FIGURE 1 The grandfather's family cleaning his bones. January 2017

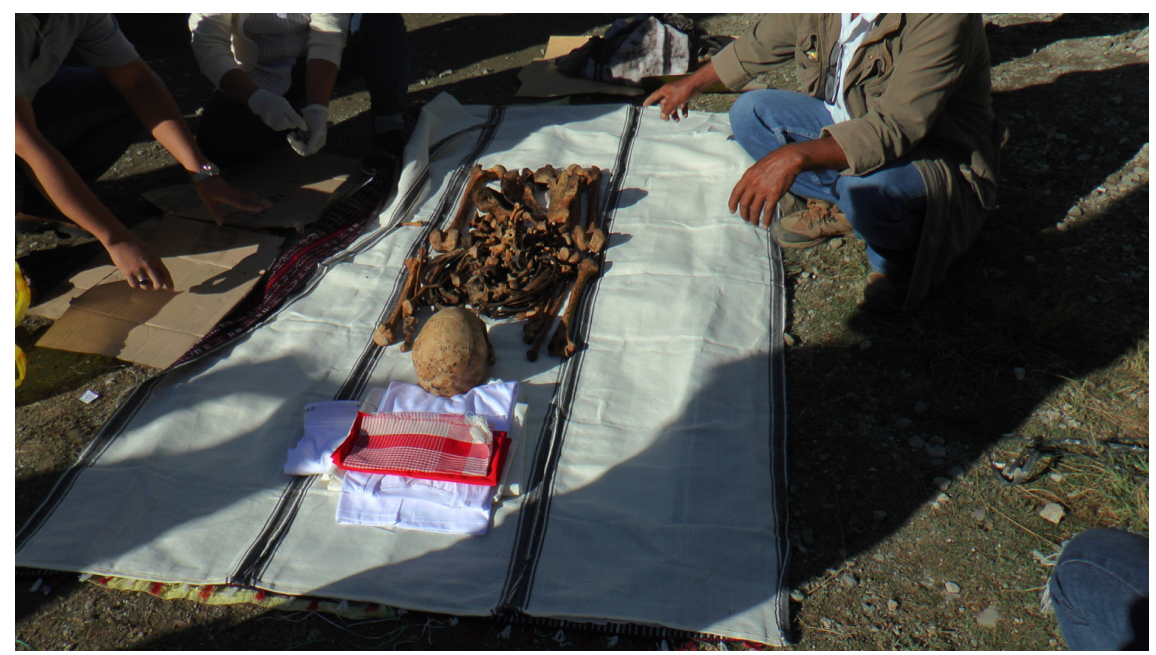

FIGURE 2 The grandfather's bones reassembled on a shindi sheet. January 2017

(metals, plastics, and termites) are removed, and a madmad is said when repositioning the bones on the new blanket and providing new clothing. ${ }^{9}$

We have to recall here that when a death occurs, the body of the deceased person is put in a white blanket (kolebaw) for a man or a black one (sapey) for a woman. Then, a second blanket is used depending on the social rank of

9 The old clothes are buried beside the grave. 


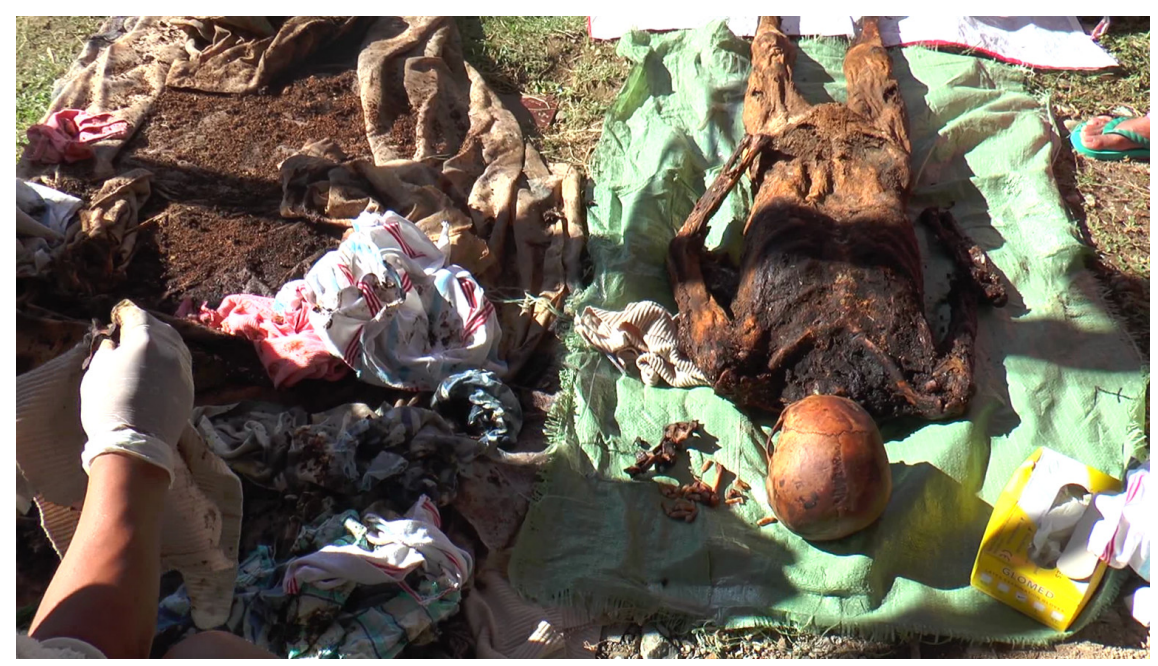

FIGURE 3 The grandson's remains are cleaned by his family. January 2017

the deceased person and on what has been used for the antecedents of the deceased. If the antecedents of the deceased used a shindi blanket (used for rich families), such a blanket has to be used as well. But if the deceased is from the middle class, a sinobel blanket would have to be used; for poor families, only a sapey and kolebaw may be used. ${ }^{10}$

Then, when the living exhume the grandson, they discover that his body and clothing are damp and his skull is cracked. The father links these observations to his own cold and migraine. The skull is cracked because the grandson died in a motorcycle accident. His clothes and sheets are damp because the tomb was incorrectly sealed and the sheets did not correspond to his status. As with the grandfather, the grandson is exhumed, and his corpse is cleaned and placed in a new sheet (see Figure 3). But suddenly, things take a turn for the worse.

As the cleaning operations come to an end, the grandfather's sister enters into a state of possession (shepo). She is possessed by the kedaring, her dead brother's spirit, who is angry. The spirit complains about the family's ignorance of Ibaloy traditions, pointing to sheet misuse-wrongful use of a kolebaw sheet instead of a sapey sheet. He also complains that during the first funeral his family failed to perform the batbat sequence (the fourth sequence of this ritual). The grandfather's kedaring threatens to carry away someone from the family 


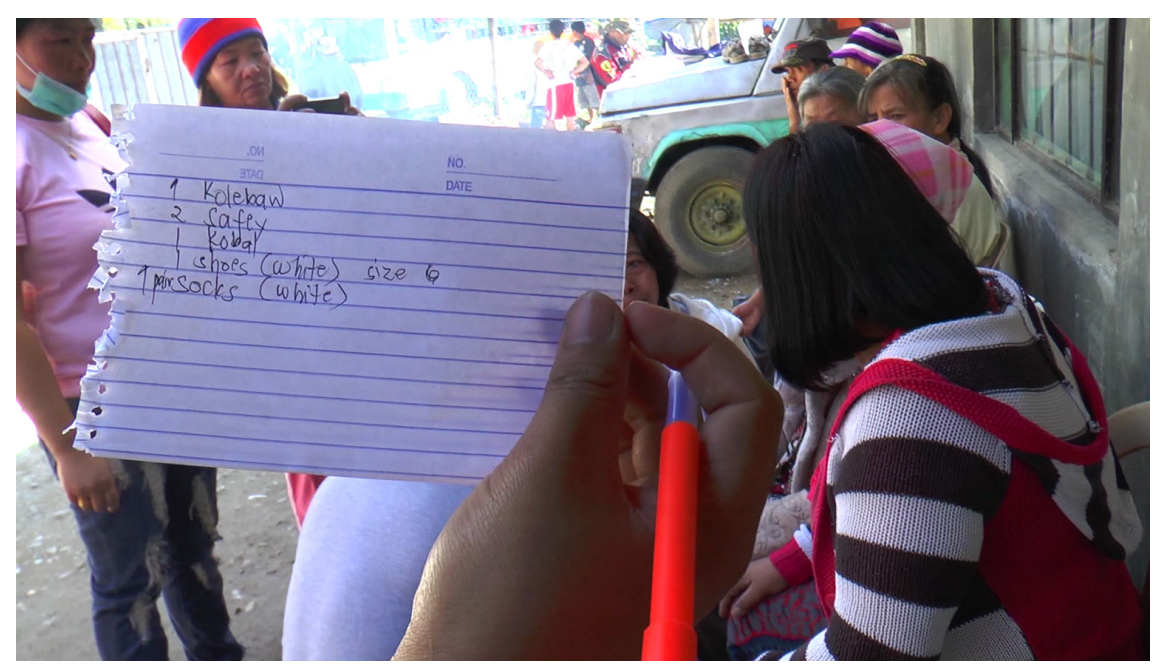

FIGURE 4 The family is taking due note of the request from the grandfather's kedaring during the possession. For example, a pair of size 6 shoes is needed. January 2017

if they disobey his request: they must perform the késheng ja waray batbat without further delay and use the right sheets. The kedaring is making specific requests, and the family is taking note of the sizes of the required clothes and shoes (see Figure 4).

Two black pigs are brought by men on their backs and butchered then and there. The first pig is for the grandfather's kedaring. It is placed near his corpse. The second pig is for the grandson and is placed a bit further away. The pig has to squeal loudly, and for this it must be made to suffer in agony. It is killed while placed on its right side, facing the rising sun. A piece of its flesh is opened up with a knife, and a sharpened stake (owik) is pushed into the wound, with care taken to avoid the heart. The death agony will last several tens of seconds before the pig is finished off with a final thrust through its heart. The two pigs are killed one after the other (see Figure 5).

The Ibaloy say the squealing is heard by the kedaring, who understand that the pig is being killed for them. It is emphasized that this squealing is the only sound that ancestors and divinities can hear. Without these cries of agony, the dead cannot join in the feast with the living.

Family members then cut the pigs up. The liver is removed first. The mambonong examines it, looking again for a padto, a sign that the ritual will succeed and produce the desired results (see Figure 6). It is a bad omen if part of the liver is missing. In that case, the family will have to butcher a new pig and keep doing so until they find one with a complete liver. The condition of the liver shows the degree of satisfaction of the kedaring, which express themselves by 


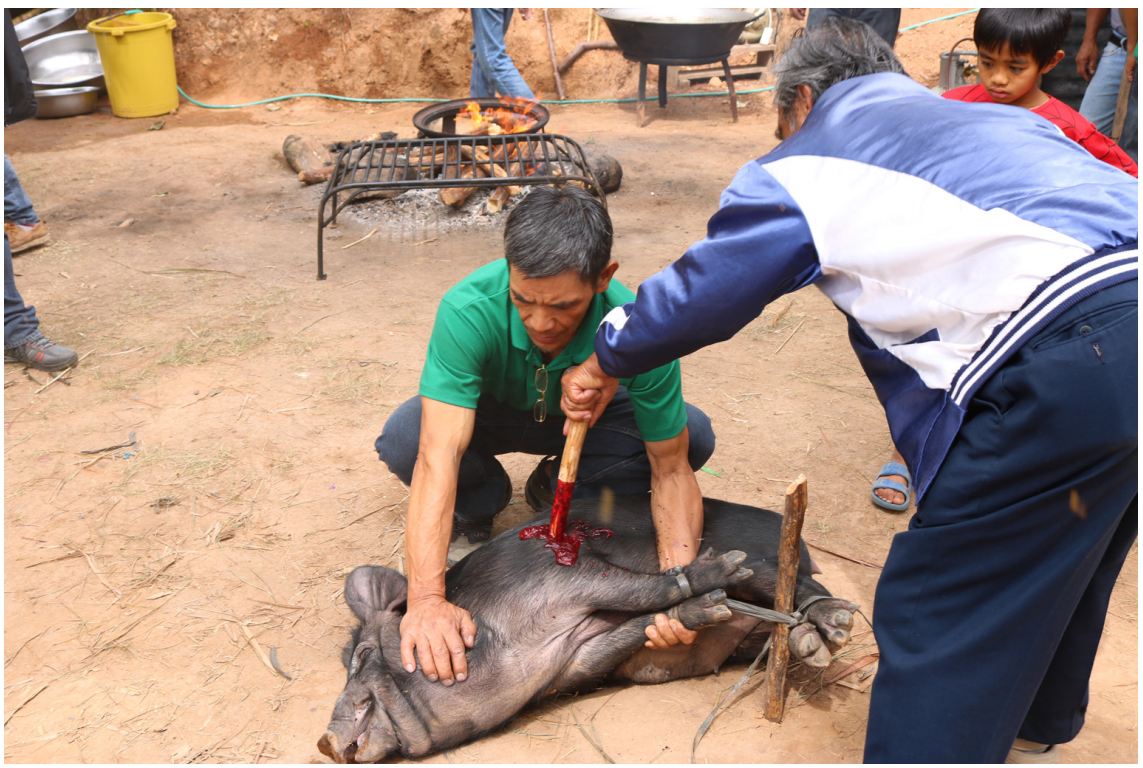

FIGURE 5 Two elders kill a pig with a sharpened stake, the owik. January 2017

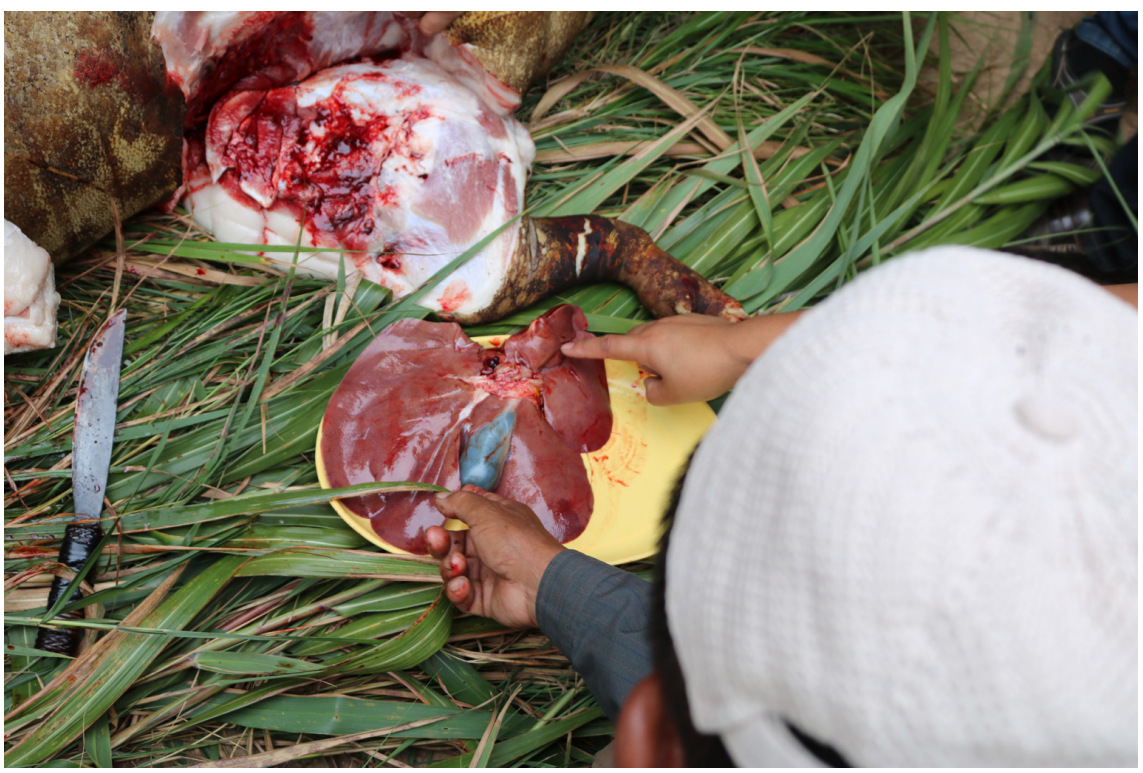

FIGURE 6 The mambonong examining a pig's liver. January 2017 
this means. The gall bladder is next separated from the liver and placed at the end of the owikstake used to kill the pig. The impaled gall bladder will finally be hung under the roof of the father's home, to show the kedaring that the family has completed the ritual sequences and honoured their requests.

The pigs are cut into pieces, cleaned, and cooked in large pots over a wood fire. They are now eaten by the family and the guests. Nothing is cast aside or wasted. According to the Ibaloy, the kedaring join in the feast with the living. They consume the steam rising from the rice and meat being cooked. They thus take the pig's karashowa with them into the aponan, one of the two post-mortem places where they live. The living eat the apag, the meat. Later, the guests will take away the leftovers (watwat) to their homes. The father is forbidden to eat the pork offered to his dead son. In the words of the Ibaloy, eating this meat would amount to the father 'devouring his own flesh or that of his offspring'. This detail evokes Rubel and Rosman's (1978) famous text, Your own pigs you may not eat. It suggests an equivalence between a pig and a human: in this situation, the Ibaloy refuse to eat pig flesh to avoid any semblance of cannibalism. Remme (2014:138-9) made a similar point about the Ifugao, who are said to view the pig as an extension of the human body.

At different sequences of the ritual, the mambonong recites bonong to the kedaring, asking them to guide the family so that the ritual may be performed fully and properly and subsequently to provide luck and a good life. The bones of the dead are put back in the tombs. The participants are careful not to lure living people or their karashowa into the next world. All of the participants must jump over a fire and wash their hands and faces with water to keep their karashowa from following the kedaring of the dead. These acts separate the dead from the living, a necessary separation when the ritual ends. Indeed, if the two worlds can be intertwined during the ritual, they have to be disconnected from each other.

\section{$2.3 \quad$ The Inkaringan Sequence}

Once the reburial is over, the ritual continues and broadens in scope with the inkaringan sequence. Pigs now have to be butchered for the kedaring of the entire extended family. Each pig is tied by a rope to a kedaring. The couples and their dead relatives are joined together, sharing the same pig. The offerings are blankets, clothes, shoes, hats, money, tobacco, juice, and alcohol (see Figure 7). While the pigs are being killed, the mambonong recites the names of the kedaring of the entire family and also those of ancestors whose names are no longer known to everyone. The mambonong says a bonong for the dead, asking them to use the offerings and adding that if anything is missing they may 


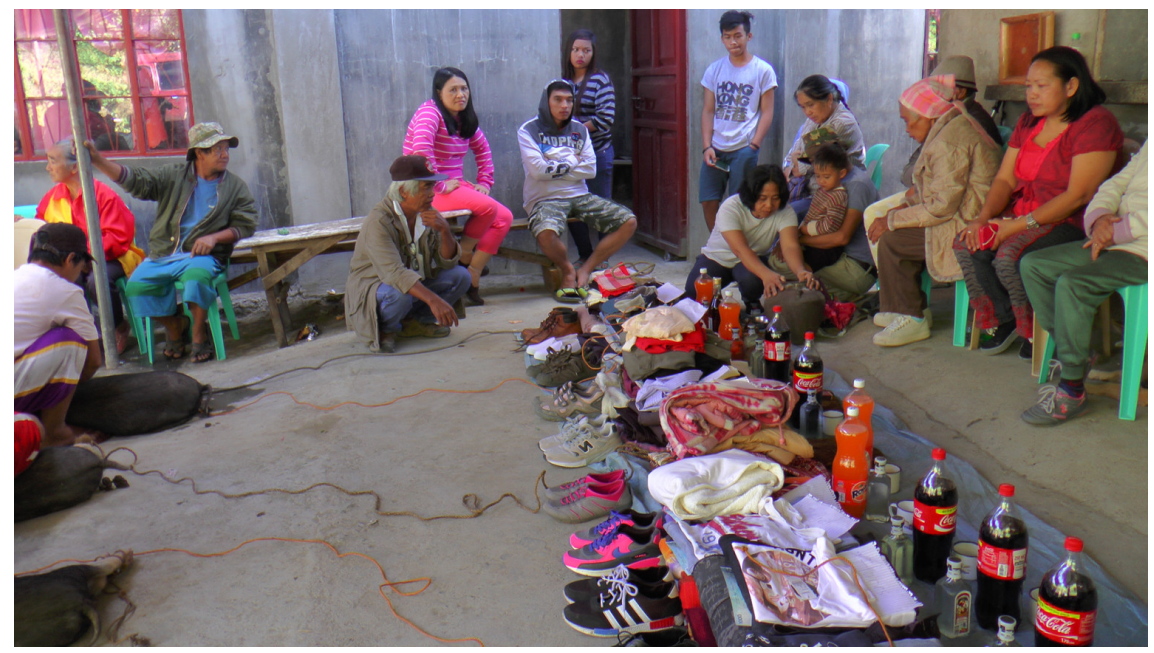

FIGURE 7 Some of the offerings and some of the pigs, tied together by ropes and offered to the dead. January 2017

always use the money they are offered to get whatever they need. Three days after the ritual has ended, all of the offerings will be taken back.

The pigs are killed the same way, with stakes. They lie on the ground in agony, on sapsap plant mats, squealing loudly and at length as expected. Each of them is butchered by two men. The pigs are cleaned, and the meat is immediately put into the cooking pot. Some pieces are roasted; others are boiled in large metal containers. Nothing is wasted. The blood on the ground must be kept away from the dogs and must not come into contact with the meat. The blessings of the kedaring are conveyed through the blood, which a woman of the family gathers in a dish at the mambonong's request. Blood is also used to anoint members of the family who have financially contributed to the ritual, thus providing a recognizable sign. Each pig's liver is finally examined by the mambonong. Part of it is cut out and taken away by the family, who will dry it and keep it in their wallet as a kedaring gift that will bring luck.

After eating, the family members dance the tayaw. Men and women form a circle of couples who advance, one behind the next, to the sound of gongs. They each represent a kedaring of the family. Each man wears a blanket around his shoulders, and each woman wraps herself up in the fabric. The men imitate an eagle flying and gliding. They raise their arms and open their hands to draw in and gather blessings and luck not only from the kedaring of their ancestors but also from the Ibaloy gods. After two rounds, the dancers drink the rice wine, imbibing the gift of luck given by the kedaring. The dance aims to bless the living family and give them long life and luck (see Figure 8). 


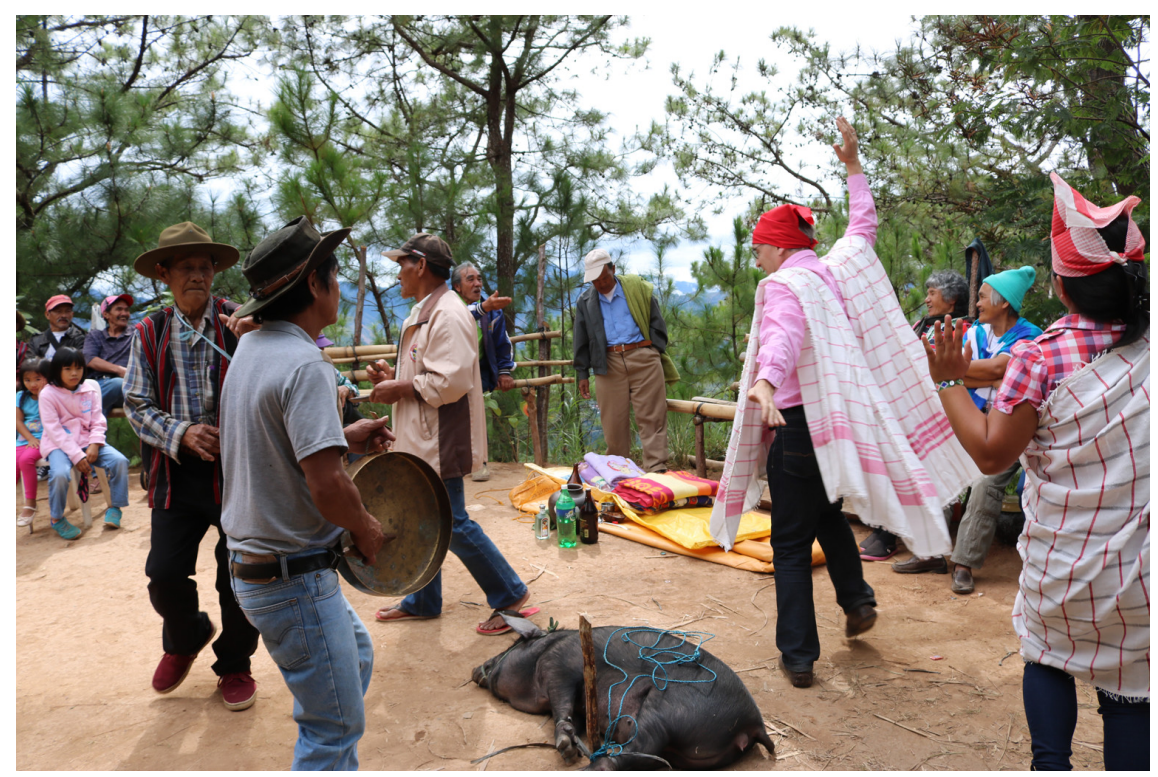

FIGURE 8 Two couples are dancing the tayaw, followed by three musicians tapping on gongs. January 2017

Through these dances the entire community is reconstituted, and the living, the kabunian, and the kedaring come together to celebrate. This unity is promising and bodes well for future luck.

\subsection{The Batbat Sequence}

The ritual continues in the evening and is now meant more for the kabunian, the Ibaloy divinities. The family again prepares offerings of blankets, clothes, drinks, and money, as well as five earthenware jars of rice wine. Each jar represents a pair of kabunian. To receive their blessings, the mambonong places one taro leaf in each jar. He then says the bonong of pasang ni adibay and throws out three pieces of meat for the kedaring and for tinmongaw, the earth spirit. The blessings will keep domestic animals, such as dogs, pigs, chickens, horses, and water buffalo, free of illness. All of these animals share their daily life with the Ibaloy and are consumed during rituals. They are part of human society; they are partners, credited as having the same interiority (karashowa) as humans.

The family members then take turns dancing around a single pig that is butchered using the same stake technique. The father holds a rope tied to the pig and a silver coin to receive luck from the kedaring. Meanwhile, the mambonong says the bonong of pasang ni bishas shi naykayang to keep the family members free of illness. Once the pig has been killed, a woman gathers its 


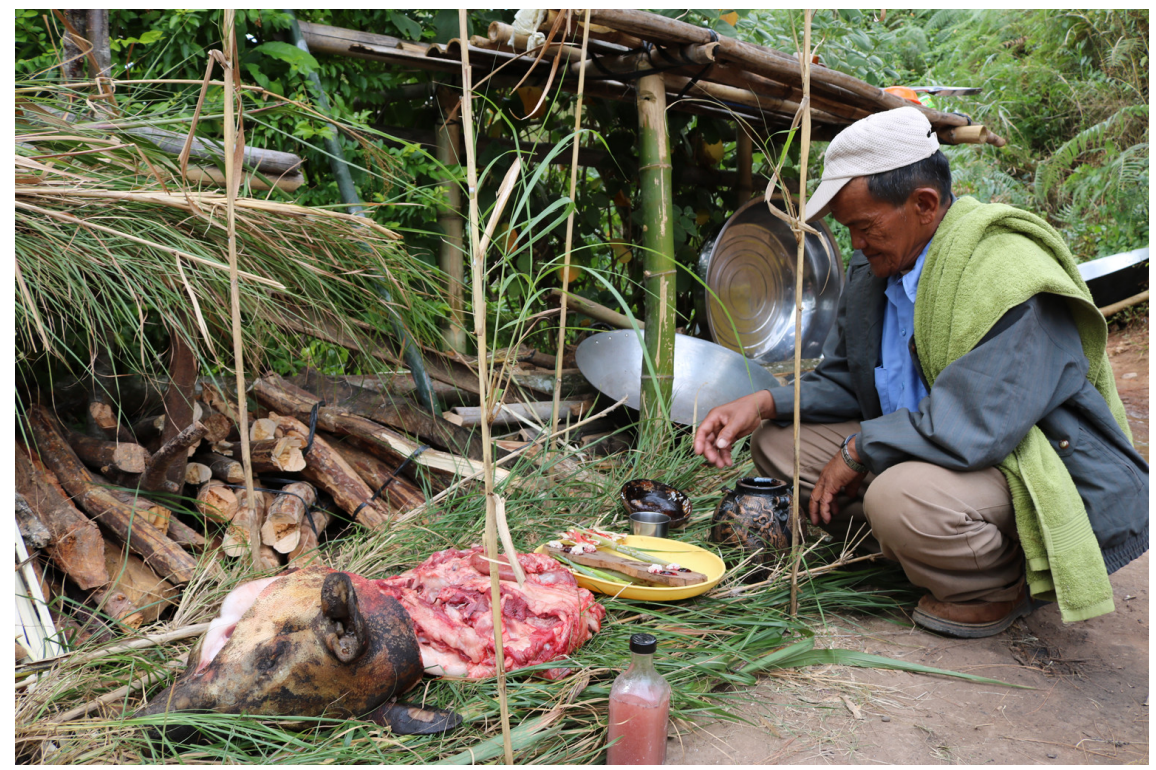

FIGURE 9 The altar of offerings to the kedaring with the four sticks. January 2017

blood, which gives tangible form to the kedaring's blessings for the family. The right front foot is roasted and held with the liver in the father's hand, while the mambonong utters the karontogan formula asking for protection from evil spirits that live in the trees and mountains and for bountiful harvests. Finally, the family members come together in a circle inside the family home.

\subsection{The Sinekgowit Sequence}

On the morning of the third day, the family members prepare the sinekgowit. They pound four sticks (sapsap) into the ground, thus forming a square on which will be placed various objects as well as the pig, which will be butchered on a plant mat (see Figure 9). The objects are the kalesay (a wooden shield), two dopis made from bamboo, betel nut, two taro leaves, an earthenware jar of rice wine, and a talyap (a round dish for the pig's blood). All of these objects serve to protect the participants from evil spirits. The pig's liver and blood are used to paint the nose and eyes of the kabunian gods on the kalesay shield in order to protect the family from evil spirits. The family will keep the pig's tail, its gall bladder, and the owik stake to bring luck and go on living a good life (see Figure 10).

After eating the pig, the father and the woman who financially contributed the most to the ritual start a new dance. The father holds the kalesay shield and the two dopis, while the woman carries the talyap dish above her head. 


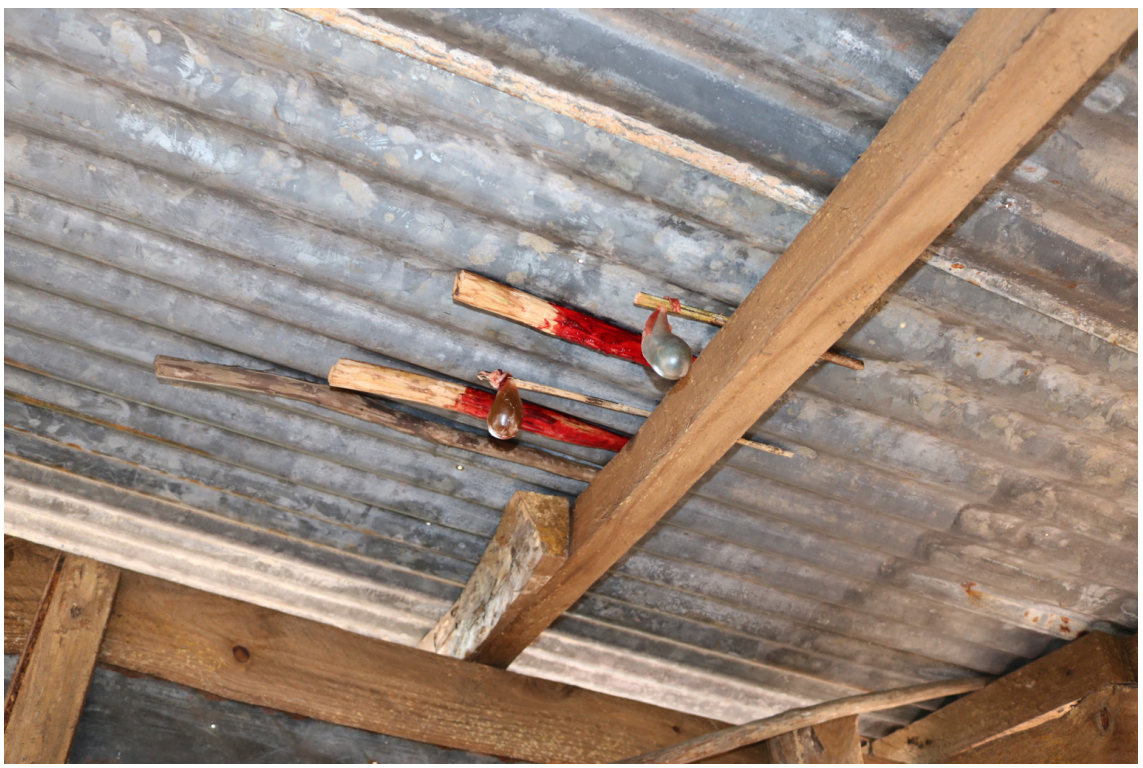

FIGURE 10 The owik stakes used to kill the pigs. The pigs' gall bladders hang from these stakes. January 2017

The mambonong says the boyag, asking the gods to help guide the family. Once the dance is over, the objects are brought inside and will henceforth remain in the house.

\subsection{The Kape Sequence}

The ritual continues in the afternoon with the kape. Using a taro leaf, the mambonong first performs the epas sequence: he calls for and catches the karashowa, the souls of family members that have wandered off during the ritual (see Figure 11). The mambonong has to name each family member without forgetting anyone. He then performs the depshit by removing a few hairs from a pig and asking the kabubian to bring health to the family. It is now the turn of the woman who was dancing with the talyap dish above her head. She collects blood from the butchered pig while performing the akop ni shala to receive the luck the kedaring have bestowed on her family. She circles around the pig, starting from the right, and then washes off the blood above the home fire, where the food is cooked. The mambonong next performs the kados, anointing the father and the woman with the pig's blood by using the owik stake, so that the kedaring may recognize them as having properly carried out the ritual. These gestures suggest that the ancestors do not know all the participants, who have to identify themselves to them. He then uses the blood- 


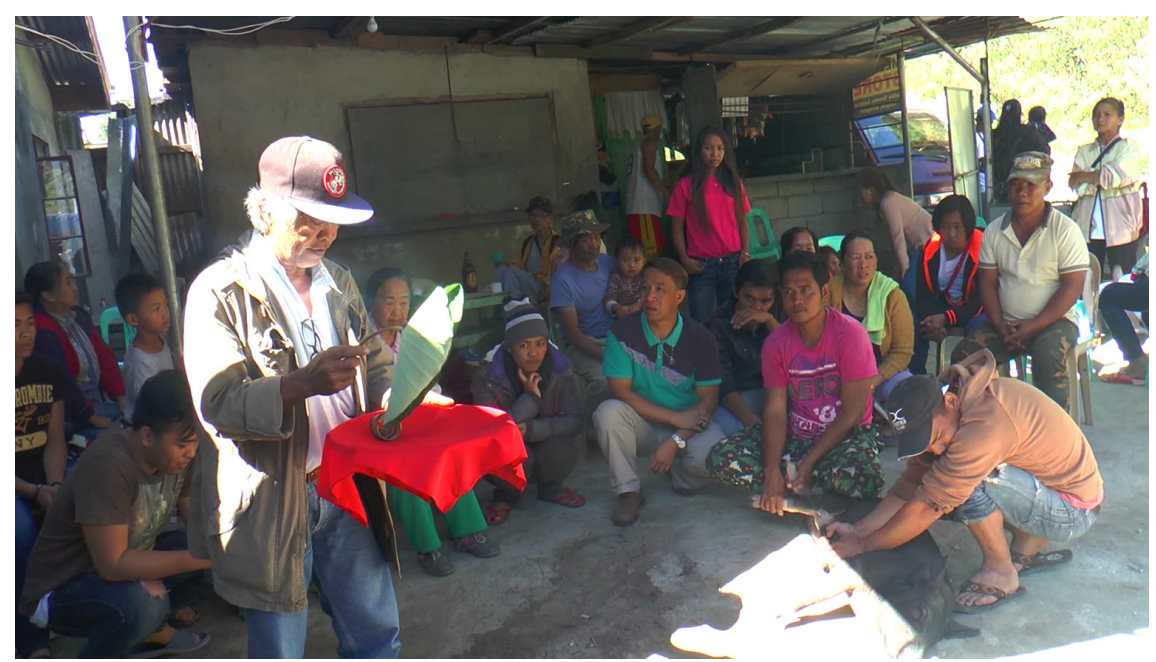

FIGURE 11 The mambonong performing the epas with a taro leaf. He summons the karashowa of the living that have wandered off. January 2017

stained stake to bless the rest of the family. This object is finally attached to the gall bladder and hung from, or placed on, a beam under the roof of the house, to show the kedaring that the family has successfully performed the késheng ja waray batbat ritual (see Figure 10).

The living have now honoured the kedaring's requests, as made in the father's dreams and during the grandfather's sister's shepo possession. For the next three days, the family members will have to respect the ngilin, the taboos. They must neither work nor have sexual relations. They must also make sure the home fire remains lit permanently. Thanks to the smoke from the fire and its light, the group expects the kedaring to visit the home and bring their luck to the family. the Ritual

Whenever the dead feel bothered or uncomfortable in their resting placewhen they lose their diteng - they contact the living, who must clean their graves and get rid of any termites, plastic, metals, or dampness. These problems are sensed by the living through correspondences. The kedaring in the other world are understood by analogy through signs in this world. At the outset of the ritual, we saw how the excessive dampness in the tomb of the grandson's kedaring was directly linked to the father's cold and migraine. If one properly 
cares for the dead in their resting place, they promise in exchange to provide health and fortune. Otherwise, they will get angry. They will come back, disturb the living, and take possession of their bodies, sowing illness and misfortune just about everywhere. To avoid this, the Ibaloy maintain strong connections with their dead, notably through rituals, but they also need to be separated from them at the right time.

In terms of its progression and timeline, the ritual begins with two sequences focused on the family of the deceased: the poni and the ka-il. The poni starts things off, and the ka-il continues with the exhumation of the corpse. With the inkaringan and batbat sequences, the ritual broadens beyond the family circle to include the entire ancestral lineage. Other pigs are needed. With the sinekgowit and kape sequences, the ritual again focuses on the circle of the extended family. Similarly, when the ritual begins, the participants speak above all to the kedaring. Then, with the inkaringan sequence, the kabunian are summoned to the scene. It is under their protection that the living exhume the remains and eat with the dead. These divinities are normally scattered in daily life but are now brought together.

Spatially speaking, the ritual is performed on one site. However, it starts on the particular area near a house where the graves are located and, gradually, the scene is enlarged. The ka-il and the inkaringan take place in a broader space with the killing of additional pigs and the tayaw dance. With the batbat and sinekgowit, the scale changes again and the focus is now put on the house of the family that needs protection from evil spirits. In the batbat, the ritual extends vertically with the pig meat that is given to kedaring but also to the tinmongaw, the earth spirit. The kape closes the process with the epas, the depshit, and the ngilin for all the participants. The latter will leave the site with the watwat, the pig meat they will bring in their homes while observing the ngilin.

Thus, the ritual seems to involve an expansion of the scope of sociality, from the near family all the way to the community, the animals, and the kabunian, as well as an expansion of time, where vitality is momentarily suspended among humans (through $n g i l i n$ ) in order to facilitate its transfer to the deceased.

\subsection{The Pig, Its Meat, and the Steam Rising from the Cooking}

For all their rituals, Ibaloy prefer using native pigs over commercial ones. Ideally, one should use their own native pigs. Because they have a great value to their owner, these pigs have subsequently more value for the dead. But for many reasons, these pigs are becoming rare, and the native pigs are now mostly bought at the local market and, when not available, replaced by commercial pigs. Some rules cannot be ignored, however, and notably for the tinmongaw, only a white pig can be used. 
During the ritual, the squealing of the dying pigs enables the living to be heard by the kedaring and the kabunian. The Ibaloy stress that these entities would otherwise not hear the words of humans. The pig is thus a sort of connector. Conversely, by examining a pig's liver, the living can find out whether or not the kedaring are satisfied with the offerings and their quality. In this act, too, the pig is a mediator. As Hamayon (1995) observed in other contexts, these acts are repeated until the participants deem the responses to be satisfactory. During the poni starting sequence, chicken blood serves as a sign. This is what the mambonong examines before exhuming the corpses. The participants like to observe the blood slowly congeal, trying, if possible, to make out numbers that the deceased has provided. Several even play the jueteng, a local lottery, immediately after the operation and use their mobile phones to communicate the numbers to a call centre.

Pig's blood conveys the blessings. It must not drip onto the ground or come into contact with the dogs, hence the use of the sapsap, a plant mat. The participants say that otherwise the dogs would carry away the blessings given by the deceased. Furthermore, if the blood makes bubbles as it spills from the pig's mortal wound, the participants see this as a sign of luck and an additional blessing. Any splashing is a good omen. Finally, if the blood spills near the animal's ears, the Ibaloy say it will bring the elders luck. The blood in itself is a sign. During the kape, we have seen it used to anoint participants who have performed the ritual, so that the kedaring will recognize them and grant them luck and protection. Just as the pig's squealing helps with communication with the deceased, its blood and gall bladder displayed on the end of the owik, the killing stake, show them that the ritual has been done correctly.

During the ritual, the pigs seem truly central to the exchanges between the living and the dead. For the Ibaloy, humans and all living things - plants, trees, and animals but also objects and food-have a karashowa. In this respect, animism also innerves their cosmology. Among the living beings, this soul, they say, takes shape in the belly but is located throughout the body. It is an immortal component, even though a non-human, mandebas, is described as a hunter and eater of karashowa. According to the elders, the kedaring especially want karashowa. They ask the living for pig karashowa so that they may raise pigs in their post-mortem world. During the meals, the participants eat all of the pork and chicken meat, and the deceased consume the dowag that rises from the pieces of meat in the large cooking pots. Only when the steam has disappeared do the living begin their meal, as the Ibaloy believe that the disappearance of the steam signals that the kedaring have finished eating and have been duly honoured. When elders were asked why pigs are central to the ritual, they replied that such animals are simply the preferred food of the kedaring. 
But other animals may be used, such as carabao. Finally, when the participants drink the rice wine, they imbibe the gift of luck given by the kedaring, as happens during the inkaringan sequence.

The living use pork to renew the cycle of exchange with the kedaring. To argue that the pigs are human extensions or animal sacrifices, as Remme (2014) said about the Ifugao, does not seem to explain what happens here during the ritual. Indeed, when the father of the family says he cannot eat any of the pork offered to his son, seeing the act as tantamount to eating his own offspring, we do not see an act of sacrifice but rather one that would compromise the cycle of giving and exchanging. One cannot give to himself. Unlike some societies of Borneo or Amazonia, where the living consume their dead (Metcalf 1987; Conklin 2001), the Ibaloy do not practise endocannibalism. They instead establish continuous relationships of exchange with their dead, hoping for reciprocity. The same can be said among the living who exchange daily favours, foods, debts, and so on. In a way, the vital force of the pig that is killed is transferred to the deceased and the agony of the pigs testifies it. Similarly, when the participants go home with the watwat (the remains of the butchered pigs), this meat will continue to bring them the blessings of the dead. It can be explained by the fact that a pig has to be eaten entirely in a logic of part-whole relationships. According to the elders, no benefit is bestowed on anyone who eats this meat and has not taken part in the ritual.

Bloch (2014) observed that the fear of being in contact with the human dead body is universal. In Loacan, the living do not show much disgust for dead flesh when the human remains are exhumed, but gloves are used and the situation is ambiguous. Certainly, the deceased's family has the delicate task of cleaning the exhumed corpse and bones, but the other participants freely join in the eating of pig flesh in situ and near the dead body, as is quite clear in our film (Laugrand, Laugrand, Tamang and Magapin 2019). However, Afable (1975:119) reports that a kind of disgust appeared over the years: 'People complain of no longer being able to remain insensitive to the obnoxious odor of a decomposing body for more than a few days; and besides, government health officers have been waging a campaign against the practice of displaying a corpse for long periods.' The pig's flesh does also disgust the deceased's parents, who cannot consume it, as shown in the film by the father's reaction. This disgust also appears during the first funeral, when some participants do not wish to eat the ritual pork because the idea sickens them. They are named the mantekili and can leave to eat other foods in a separate house.

Besides pork, many other objects are offered, such as clothes, shoes, alcohol, tobacco, and cigarettes. These objects and the money are taken back by the participants after the ritual. Sometimes, as seen here during the possession, the 
deceased may demand specific sizes and colours. The living have to give them either these exact things or money, which the deceased can use to get whatever they wish in case of dissatisfaction with the offerings. Such a detail is interesting as it shows how much the living want to make sure they answer to the needs of the deceased.

\subsection{The Dangers of the Feast}

Dead people are dangerous and the living want to make sure that they will not return to haunt them. This is partly why those who died by accident or suicide are treated separately in the poni sequence. Few of these dead may reappear roaming around and bother the living. Bringing the living and the deceased together, even under the protection of the kabunian and the guidance of the mambonong, is also dangerous.

First, the feast cannot last forever. The dead and the living will have to go back to their respective worlds. It is important to know how to break off this relationship, as is done at the end of the ka-il, when the participants jump over the fire and wash their faces and hands, as if to disconnect from the world of the dead. Whatever the funerary ritual, the participants also wash their faces and hands before going home.

Communication with the kedaring is not without risk, and people have to protect themselves from evil spirits. This is suggested by the sinekgowit sequence, when the participants use a 'shield', betel nut, taro leaves, and an earthenware jar of rice wine. Using the pig's blood, they draw a depiction of a kabunian on the shield to protect the family from evil spirits. The kape final sequence shows the key role of the mambonong, who in turn helps protect the family by summoning and catching all of the karashowa, the souls of family members that wandered off during the ritual. During this epas ritual, he will name each karashowa and must not forget anyone. All of this suggests that the living are at risk of merging with their departed loved ones and that these two groups must remain apart, except during the time of commensality organized by the ritual. Once the ritual is over, the family that performed it will expect to receive blessings and luck from the kedaring. The family is identified by them through the home fire, and the participants enter a phase when sexual relations and work are prohibited (ngilin). These practices mirror each other, as if the dead cannot fully express their vitality unless the living put a halt to theirs.

Today, these rituals are criticized by the evangelical Protestant churches, which judge them to be too costly and ostentatious. Yet, in the community of Loacan, many believers from these churches still participate in the death rituals. Some complain though that people just 'come and eat the food'. The 
Catholic Church tolerates these practices, calling them 'thanksgiving' rites. However, to the elders, Christianity offers no equivalent way to ensure good relations between the living and the dead. While affirming their Christian identity, the Ibaloy carry on their exhumation rites. At times, they might use a rosary to call the karashowa of the living persons in the epas, but otherwise no other Christian symbols are present. And the same applies for the aremag-a novena and prayer can be added to the first funeral, but they never replace the rituals.

The kedaring are said to live in two post-mortem places: the aponan and the dangit (sky). Missionaries have used the second term for the Christian concept of heaven, but they have not managed to erase the belief that the deceased can still communicate with the living, unlike souls in heaven. Conversely, the living can help the dead go from the aponan to the dangit and can clean their remains to ensure their final transformation into kaapoan, anonymous ancestors. ${ }^{11}$ Those who follow the traditions of the past also fear that the younger generations are forgetting which objects, such as sheets, were used in their parents' funerals and the location of their bones. In this ritual, the possession clearly illustrates the consequences of the loss of this kind of memory, as the family used the wrong blankets.

\section{$4 \quad$ Conclusion}

The késheng ja waray batbat reflects Hertz's idea that in many societies in Southeast Asia and elsewhere death is a slow and partial transformation that culminates in becoming an ancestor. Nonetheless, this ritual suggests limits to his approach. The dead remain as invisible living beings that the Ibaloy feed and look after by offering food, clothing, alcohol, tobacco, and pork. Although they are dead, they still strive to reach a state of diteng, and obtain vitality. The deceased live in a sort of parallel world to that of the living, and they continue to participate in exchanges with their relatives throughout their journey.

Mauss's (2002 [1924]) classical study of the gift helps to understand these ongoing exchanges. Mauss was fascinated by the notion of the gift, postulating that each gift required a counter-gift. This applies well to relations within

11 If the Ibaloy cannot remember the name of the kaapoan, they are not forgotten in rituals: one set of offerings is always given to them. When he recites a bonong, the mambonong asks the kedaring to kindly share their offerings with the kaapoan who need it. Just like the living, the dead continue to make exchanges among themselves in their post-mortem places. 
society where human beings are by definition social beings, but it is more difficult to apply to beings who lack a social nature, such as the dead, who lose their names and are no more subject to the life cycle but nonetheless give and receive. Yet, as the Ibaloy conceive their dead as 'duplicates' of human beings, the logic of the gift operates. Receiving pig's vapour (dowag) and pig's karashowa, the dead are expected to reciprocate later to the living ones. Exchanges thus create connections between the living and their deceased but also establish them as separate partners (Strathern 1988). But the living will remain indebted as they cannot reciprocate with a gift of equal value to what they get from the dead. However, as Mauss noted, the gifts to the dead oblige them in return. Under the kabunian, general reciprocity as defined by Sahlins $(1976)$ is at play. Solidarity is high between the exchanging partners and the value of the gifts is limited to meat, clothing, and drinks.

Pigs are indeed very present in the local exchange system and they are again central to these relationships, which brings us to a second theoretical point: the concept of person. As Remme (2014:7) makes clear for the neighbouring Ifugao, the Ibaloy do not define a person as a unique entity but, instead, as dividually and individually conceived (Strathern 1988:13), meaning that a person contains aspects of both individuality and relationality. The notion of karashowa, or kadkadwa, is here notable as it literally translates as the 'second', pair, or double of the living body, and can easily wander off during dreams or rituals - times and places where they are closely connected to the deceased. Thus, the Ibaloy consider that a person is in a state of diteng only if rituals have been respected and if the dead are themselves in a similar state. Performing rituals and exchanges with the dead brings them good health, wealth, and luck, all of which will be returned to the deceased again. In the final analysis, because the Ibaloy cannot break the tie with their dead, they seek them out and try to turn them into social partners. They exchange pigs with them and hope to receive fortune in return for proper ritual treatment of their remains. They wish to get blessings and success that only the dead can offer to their loved ones. In contrast to other exhumation rituals, like those performed by the Bamileke of Cameroon, there is no veneration of ancestors, no statuary art, nor any form of relic cult among the Ibaloy. As among the Yukpa of Colombia (Halbmayer 2013), the deceased remain connected to the living at all times.

This ritual also shows that one must use the agonized squealing of pigs to summon the kedaring and honour their requests in order to enjoy their blessings and protection in return. This squealing of the pig is essential. It works as a call to be heard by the invisible beings, as a connection, and as a sign for the dead that some vitality is now transmitted to them. Building on Bloch and Parry's (1982) perspective, regeneration takes place not only during the ritual 
through the killing of a pig and the cooking of its meat (through the dowag), but also continues afterwards, when the deceased are invited on a daily basis to eat the meal prepared by the living. Smell thus appears to be an important part of the communication between the living and the dead.

The Ibaloy say the késheng ja waray batbat ritual may be repeated indefinitely at the request of the kedaring. It is preferably done with exhumed human remains, but they can be very little, even fragments. The ritual is also always an opportunity to speak to all of the dead, even those who have not been exhumed, do not belong to the family, or are not personally remembered. In contrast to many hunting cultures, the dead of the Ibaloy are not transformed into game or food for the living. They become invisible beings able to travel, but they continue to need clothing, food, pigs, and money. In some areas, like Kabayan, in a distant past, the dead were made into mummies to preserve their remains, but these traditions are no longer present.

The ritual can be approached as a solution to an incidental crisis, when a problem arises in the family or the community. It is a key moment in commensality and in exchange of goods, food, and vitality. The dead and the living mutually ensure a good life and the means to get ahead in their respective worlds. The Ibaloy continue to think that the dead have left for other worlds while still remaining nearby, having been placed in tombs and buried near their homes. To forget them immediately is to risk paying a high price. Nonetheless, to enter into communication with them is also risky and dangerous, hence the summoning of the kabunian gods and the necessary presence of a mambonong, who alone can bring back the souls of the living that have wandered off during the ritual.

For anthropologists, Ibaloy exhumation rites are challenging. They fit poorly into the 'double funeral' concept. On the one hand, they can be repeated indefinitely. On the other, the dead continue to interact with the living, who otherwise cannot live a good life. The dead also seem similar to the living. Though nonmaterial and invisible, they likewise raise pigs, need money, and continue to consume resources. The living participate in exchanges with them. The Ibaloy stress that to live a full life, one must follow the funerary rituals in every detail and never turn one's back on the dead (Laugrand et al. 2o1gb). Exhumation thus gives the living an ideal opportunity to show respect for the dead. If not, sickness and bad luck will come. As Lola Juana Willy remembers, dead people can even be violent towards the living. She relates:

I experienced one, I saw a spirit of a deceased person. I was in this side and he was on the other side. When we met at the center, he threw me down, that's why I have sore skin and I did not yet heal from that ... But the spir- 
its of the deceased people who died long time ago are okay, because you would just see and meet them without them touching you.

LAUGRAND et al. 2019a:171

Viewed from a broader perspective, these exhumation practices seem especially present where analogism predominates, to use a term coined by Descola (2005:277), as if they were, along with sacrifice and possession, a means to connect to others in a context where all existing entities are considered to be singularities that may be interlinked. Among the Ibaloy, life and death are not only two opposing worlds but also two contiguous worlds where very close relationships are established in daily life between the living and the dead.

Through commensality, the living and the dead unite before the benevolent divinities: the kabunian. This interdependence of the living and the dead characterizes Ibaloy societies, being the basis for the continuous exchange we have described and analysed. The living need the dead and vice versa. Far from commemorating or worshipping the dead, the Ibaloy interact with them and help them move on to a new life. Here, the immobility of the living gathering and eating together in the ritual contrasts with the mobility of the dead. While the dead move on to their post-mortem places, the living come together and reaffirm their solidarity with them. As a counterpart, if the deceased feel well, they will send luck and health to the living, who can then feel good. Individuality and relationality are working together here.

Like in many cultures, the dead of the Ibaloy of Loacan are considered to have their own lives. They never really disappear, as argued by Despret (2019) in Au bonheur des morts in a different context. Yet the dead need the living to travel and live in their post-mortem places, and this is certainly a feature quite common in Asia but not in the West.

\section{References}

Afable, P.O. (1975). 'Mortuary ritual among the Ibaluy', Asian Folklore Studies 34-2:10326.

Bagamaspad, A. and Z. Hamada-Pawid (1985). A people's history of Benguet. La Trinidad: Benguet, Benguet Provincial Government.

Ballard, D.L. (1978). 'Inibaloi metaphors', Notes on Linguistics 7:21-8.

Berthod, M.A. (2005). 'La vie des morts dans le regard des anthropologues', Anthropos 100-2:521-36.

Bloch, M. (1971). Placing the dead: Tombs, ancestral villages and kinship organization in Madagascar. London: Seminar Press. 
Bloch, M. (1993). 'La mort et la conception de la personne', Terrain 20:7-20. http:// journals.openedition.org/terrain/3055 (accessed 14 June 2019).

Bloch, M. (2010). 'Commensalité et empoisonnement', La pensée de midi 30:81-9. https://www.cairn.info/revue-la-pensee-de-midi-2010-1-page-81.htm (accessed 14 June 2019).

Bloch, M. and J. Parry (eds) (1982). Death and the regeneration of life. Cambridge: Cambridge University Press.

Cabellero, E. (1996). Gold from the gods: Traditional small-scale miners in the Philippines. Quezon City: Giraffe Books.

Canilao, M. (2011). Of gold, Spanish conquistadors, and Ibaloy generational memory. Baguio City: Cordillera Studies Center, University of the Philippines Baguio.

Canol, L. (1981). 'Death rituals among the Benguet Kankanaes', Saint Louis University Research Journal 12-1:37-72.

Cederroth, S., C. Corlin and J. Lindström (eds) (1988). On the meaning of death: Essays on mortuary rituals and eschatological beliefs. Stockholm: Almqvist and Wiksell.

Celino, S. (1990). Death and burial rituals and other practices and beliefs of the Cordillerans. [PhD thesis, University of Baguio, Baguio City.]

Chimcas, A., G.A. Tigo, V.B. Mesa, L. Ballard and P.O. Afable (2011). Ibaloy dictionary: Phonology, grammar, morphophonemics: Notes on Ibaloy cultural history. Baguio: Diteng Inc. and the Cordillera Studies Center, up Baguio.

Conklin, B. (2001). Consuming grief: Compassionate cannibalism in an Amazonian society. Austin: University of Texas Press.

Conklin, H., P. Lupaih and M. Pinther (1980). Ethnographic atlas of Ifugao: A study of environment, culture, and society in Northern Luzon. New Haven, CT: Yale University Press.

Couderc, P. (2007). 'Les rites de la mort à Bornéo: Séparation ou renaissance? Actualité de Robert Hertz', Moussons 11:211-25.

Couderc, P. and K. Sillander (eds) (2012). Ancestors in Borneo societies:Death, transformation and social immortality. Copenhagen: NIAs Press.

Delaplace, G. (2009). L'invention des morts. Sépultures, fantômes et photographie en Mongolie contemporaine. Paris: EPHE.

Descola, P. (2005). Par-delà nature et culture. Paris: Gallimard.

Despret, V. (2019). Au bonheur des morts. Récits de ceux qui restent. Paris: La Découverte.

Godelier, M. (2014). La mort et ses au-delà. Paris: CNRs éditions.

Halbmayer, E. (2013). 'Securing a life for the dead among the Yukpa: The exhumation ritual as a temporary synchronization of worlds', Journal de la société des américanistes 99-1:105-40.

Hamayon, R. (1995). 'Pour en finir avec la «transe» et l'«extase» dans l' étude du chamanisme', Études mongoles et sibériennes 26:155-90. 
Hertz, R. (1928). [1907] 'Contribution à une étude sur la représentation collective de la mort', Sociologie religieuse et folklore, pp. 1-83. Paris: PUF.

Huntington, R. and P. Metcalf (1979). Celebrations of death: The anthropology of mortuary ritual. London: Cambridge University Press.

Laban, A.B. (1995). 'Indigenous death and burial rituals and practices of the people of Tadjan, Mountain Province'. [Master's thesis, University of Baguio, Baguio City.]

Laugrand, F., A. Laugrand, G. Magapin And J. Tamang (eds) (2019a). Lifestories of the Ibaloy from Upper Loacan. Itogon (Philippines), vol. 1. Louvain-la-Neuve:Presses universitaires de Louvain.

Laugrand, F., A. Laugrand, G. Magapin And J. Tamang (eds) (2019b). Connecting life and death: Rituals, prohibitions and spirits. Ibaloy Perspectives (Itogon, Philippines), vol. 2. Louvain-la-Neuve: Presses universitaires de Louvain.

Laugrand, F., A. Laugrand, G. Magapin And J. Tamang (eds) (2019c).Looking for signs: Animals, spirits and death rituals. Ibaloy Perspectives (Itogon, Philippines), vol. 3. Louvain-la-Neuve: Presses universitaires de Louvain.

Lewis, M.W. (1992). Wagering the land: Ritual, capital, and environmental degradation in the Cordillera of Northern Luzon, 1900-1986. Berkeley: University of California Press. http://ark.cdlib.org/ark:/13030/ft2d5nb17h/ (accessed 14 June 2019).

Mauss, M. (2002) [1924]. The gift: The form and reason for exchange in archaic societies. London: Routledge.

Metcalf, P.(1982). A Borneo journey into death: Berawan eschatology from its rituals. Philadelphia: University of Pennsylvania Press.

Metcalf, P. (1987). 'Wine of the corpse: Endocannibalism and the Great Feast of the Dead in Borneo', Representations 17:96-109.

Moss, C.R. (1920). 'Nabaloi law and ritual', University of California Publications in American Archaeology and Ethnology 15-3:207-342.

Moss, C.R. and A.L. Kroeber (1919). 'Nabaloi songs', University of California Publications in American Archaeology and Ethnology 15-2:187-206.

Piluden-Omengan, D.E. (2004). Death and beyond: Death and burial rituals and other practices and beliefs of the Igorots of Sagada, Mountain Province, Philippines. Quezon City: Giraffe Books.

Prill-Brett, J. (1992). 'Ibaloy customary law on land resources'. Baguio City: Cordillera Studies Center, University of the Philippines Baguio. [Working paper 19.]

Pungayan E. (1980). 'Kinship structures among Benguet Ibaloys', Saint Louis University Research Journal 11-1/2:1-54.

Pungayan, E. and I. Picpican (1978). 'Ritual and worship among the Benguet Igorot', Saint Louis University Research Journal 9-3/4:46o-93.

Remme,J.H.Z. (2014). Pigs and persons in the Philippines: Human-animal entanglements in Ifugao rituals. New York: Lexington Books. 
Rubel, P. and A. Rosman. (1978). 'Your own pigs you may not eat': A comparative study of New Guinea societies. Canberra: Australian National University Press.

Russell, S. (1989). 'Ritual persistence and the ancestral cult among the Ibaloi of the Luzon Highlands', in: S. Russell and C. Cunningham (eds), Changing lives, changing rites: Ritual and social dynamics in the Philippine and Indonesian Uplands, pp. 17-44. Ann Arbor: Michigan Studies of South \& Southeast Asia.

Sahlins, M. (1976). Âge de pierre, âge d'abondance. Paris: Gallimard.

Scott, W.H. (1958). 'A preliminary report on upland rice in Northern Luzon', Southwestern Journal of Anthropology 14-1:87-105.

Scott, W.H. (1994). 'Igorot responses to Spanish aims: 1576-1896', in: D. Tolentino (ed.), Resistance and revolution in the Cordillera, pp. 1-32. Baguio City: University of the Philippines Baguio.

Shedden, R. (2012). 'Kalinga binaliwon blankets, Northern Luzon, Philippines', in: M.C. Howard (ed.), Textile traditions in contemporary Southeast Asia: Studies in the material culture of Southeast Asia 17:73-84. Bangkok: White Lotus Press.

Simon, L. (2019). Ecouter les résonances du monde. Rapports aux humains et aux nonhumains chez les Wayùu de Colombie. Paris: Karthala.

Strathern, M. (1988). The gender of the gift: Problems with women and problems with society in Melanesia. Berkeley: University of California Press.

Wilder, W. (2003). Journeys of the soul: Anthropological studies of death, burial and reburial practices in Borneo. Williamsburg: Borneo Research Council. [Monograph Series 7.]

\section{Filmography}

Bloch, M. (2014). 'Peut-on généraliser à propos de la manière dont on se débarrasse des morts?.' Inaugural Conference, 1st annual colloquium of the MAE, Le funéraire. Mémoire, protocoles, monuments, 18-20 June. http://www.mae.parisnanterre.fr/maurice -bloch-peut-on-generaliser-a-propos-de-la-maniere-dont-on-se-debarrasse-des-m orts (accessed 14 June 2019).

Fournel, A. (1962). Exhumation. Paris: SFAv. [16 mm film, 18 minutes.]

Iteanu, A. (2019). 'Livre 7. Un rituel c' est comme un flash. Relations, partages et système rituel chez les Orokaiva', Les Possédés et leurs mondes. https://www.youtube.com/ watch?v=oRxjoDS83DI (accessed 14 June 2019). [26 minutes.]

Laugrand, F., A. Laugrand, G. Magapin And J. Tamang (eds) (2019). Késheng ja waray batbat: The exhumation of human bones in an Ibaloi community. https:/youtu.be/ NFUS9aSpgjw (accessed 14 June 2019). [Film, 63 minutes.] 